\title{
Die voorkoms en betekenis van gebede in die Ou Testament
}

\author{
E.J. Smit \\ Departement Bybelkunde (Emeritus) \\ Potchefstroomse Universiteit vir $\mathrm{CHO}$ \\ POTCHEFSTROOM
}

\begin{abstract}
The occurrence and meaning of prayers in the Old Testament

In this article the most important elements of prayers in the Old Testament are used to serve as indicators for our present-day prayers. The key words and phrases for prayer in the Old Testamem are discussed, while the form and contents of prayers in different periods of the Old Testament are considered to establish the main trends in the development of prayer according to differem sitwations in the history of the people of 1 srael. A random selection of prayers from the differemt periods, with the exception of the prayers in the book of Psalms, are analysed to suggest some importamt indicators in understanding our relation toward God in our own prayers.
\end{abstract}

\section{Inleiding}

Die wesenlike eienskappe van die gebed in die Ou Testament verskil weinig van die gebed in ons eie tyd. Soos die gelowige van die Ou Testament voor Jahwe Elohim gestaan het, staan ook ons in ons gebed voor die hoë en heilige God van hemel en aarde, Skepper en Onderhouer van alles wat bestaan, Vader van die gelowiges, tot Wie die gelowige in nederige eerbied nader. Terwyl die gelowige sy eie swakheid bely teenoor die groot en alomteenwoordige krag van God, kan hy voor Hom sy skuld bely en Hom om vergifnis smeek, met die sekerheid dat God wil vergewe, hoewel Hy die sonde nooit ongestraf laat bly nie (Eks. 34:7). Van hierdie God kan die gelowige alles vra wat hy nodig het, en in Hom kan hy sy hoogste vreugde vind.

Daar is inderdaad min dinge wat die innige vertrouensverhouding tussen die gelowige en Jahwe so goed uitdruk as juis die gebed. Wat ons uit die Ou Testament leer oor die bediening van die gebede, is daarom ook vandag vir ons van kardinale belang vir ons lewe voor God. In die Ou Testament is die gebede nie net die uitdrukking van die stand van die verhouding van die volk tot Jahwe nie; dit ook. Dit leer ons egter ook iets oor die verhouding van die gelowige volk onder mekaar voor Jahwe, die God aan Wie almal gelykelik verbonde is deur uitverkiesing, geloof en roeping. Ook leer dit ons iets, hoewel minder 
geaksentueerd, oor die verhouding van die gelowige tot die heidennasies, oor wie God eweneens regeer, maar wat Hom nie ken nie.

Die gebede spreek van 'n bewoënheid oor die diepe nood van die indiwidu of die volk, maar eweneens spreek dit van die absolute eis dat God se eer tot sy reg moet kom in die midde van sy gelowige volk, en tewens in die midde van alle nasies van die wêreld.

\section{Woorde vir gebed}

Die twee woordstamme wat meestal vir "bid" of "gebed" gebruik word in verskillende formasies en vorme, is ' $t r$ en $p / l$ hitp. Albei druk die gedagte uit van voorbidding doen (Hamilton, 1981:726; Albertz, 1976:386), maar by 'tr staan die gedagte van jouself verneder, smeekbede doen, God se toorn stil, sterk op die voorgrond (Allen, 1981:709). Dikwels is die gebed nie in die openbaar nie, maar in afsondering tot God gerig (Albertz, 1976:386).

Terwyl 'tr ongeveer 20 maal verspreid deur die Ou Testament voorkom, kom pll hitp 79 maal voor, en die naamwoord hiervan, tefillah, 77 maal. Merkwaardig genoeg kom dit nie in die Pentateug voor nie, en die boeke waarin die werkwoord en naamwoord die meeste voorkom, is Samuel, Konings, Kronieke, Jesaja en Jeremia, en die naamwoord in Psalms. Waar die betekenis van "voorbidding doen" sterk benadruk word, is dit veral mense in ampsposisies wat hierdie taak verrig, byvoorbeeld Abraham en Moses (in latere beskrywing), Samuel en Jeremia (Stähli, 1976:428), maar inderdaad nooit die priester nie. Gewoonlik word voorbidding gedoen vir die volk, die koning, soms vir 'n enkeling, en ook selfs vir 'n vyandige volk (Jer. 29:7) (Stähli, 1976:429). Hıerdie woorde vir gebed word dikwels verbind aan die klaagliedere van die volk of die enkeling.

Gebede word in die Ou Testament nóu verbind met die offers. Veral die werkwoord ir word gebruik in verband met gebede by die offers. Ons het egter nie in die Ou Testament 'n voorbeeld van die "offergebed" nie, behalwe die bekende belydenis in Deuteronomium 26:5 e.v., 13 e.v. Dit kan aanvaar word dat, afhangende van die situasie met betrekking tot die Ou-Testamentiese offer, die offeraar sy hart in gebedswoorde voor God uitgestort het, byvoorbeeld by die sondoffer, die dankoffer en dergelike offers.

Naas hierdie bekende woorde vir gebed, kom 'n antal woorde voor in die "sfeer van die gebed" (Hermann, 1935). Gewone woorde vir "sê", "spreek", en dan woorde met 'n sterker emosionele toon, soos "roep", "skreeu", "om hulp skreeu", "sug", “steun", “ween", "smeek", veral "om genade smeek" (Hermann, 1935), word in hierdie verband gebruik. Wanneer die bidder in 'n gesindheid van eerbied en lofprysing tot God nader, is dit veral woorde van roem, lofprysing ( $h$ ll Pi) en die bekende Halleluja, of die betoning van dank met gebruikmaking van 
die werkwoord jdh Hif: "prys", "prysend erken", en die naamwoord tôdah, "lofprysing", wat gebruik word, en ook ander woorde vir die roem en prys van God se genade en sy werke, soos "sy werke in herinnering bring", "sy Naam groot maak", "sy lof sing".

Kortom, by al die woorde wat in die Ou Testament gebruik word om uitdrukking te gee aan die wyse waarop die bidder voor God verskyn, kan die mens in sy volle menswees geken word, in al sy emosies van verlange, versugting, smeking, nederige erkenning van sy eie onmag voor die hoë God. Fasette van menswees wat ook betrek word, sluit in die mens se dank, sy roem in die Here, sy lof aan die God van sy heil en sy vrolike, jubelende ekstase oor die verlossing wat die Here bewerk. Daarom kan die mens bly wees, dit jubelend uitskreeu, sing en musiek maak en vrolik wees voor God, maar hy kan ook smeek en huil, sy sonde bely, God roep om reg te laat geskied en selfs God se wraak uitroep oor die onregdoener en die vyand.

Die gebed het in al die kultiese handelinge van die Ou Testament steeds 'n groot rol gespeel. Hoewel Levitikus 1-7, wat die voorskrifte vir die offers daarstel, nie melding maak van gebede by die offers nie, is dit uit latere uitsprake (byvoorbeeld in Amos) duidelik dat die gebed en ook sang en musiek, die offers begelei het (De Vaux, 1973:390). 'n Groot aantal van die liedere in die boek Psalms getuig van die gebede wat tydens die offerritueel voorgedra of gesing is (Kraus, 1988:passim), hoewel dit maar moeilik bly om spesifieke psalms aan spesifieke offers te verbind.

'n Algemene snit deur die Ou-Testamentiese gebede, met 'n kort bespreking van die vernaamste elemente van enkele van die gebede, help ons om die gebede te plaas en in hulle konteks te waardeer.

\section{Die gebed in die patriargale periode}

In die patriargale periode vind ons in die gebede 'n groot vrymoedigheid en 'n kinderlike vertroue, gepaardgaande met 'n sterk houding van nederigheid. Van die bekendste gebede in hierdie periode is dié van die dienaar van Abraham wanneer hy vir Isak 'n vrou gaan haal (Gen. 24:12 e.v.: 'Here God van Abraham, ... hier staan ek by die fontein terwyl die dogters van die manne van die stad uitkom om water te skep"). Hy bid nie ter wille van homself nie, maar hy bid God om guns te bewys aan Abraham deur die regte vrou vir Isak aan te wys. Hierdie hoofstuk is al getipeer as miskien die heel mooiste van alle verhalende hoofstukke in die hele Ou Testament - veral op grond van die kinderlike gebed wat daarin voorkom (Kittel, aangehaal deur Norel, s.j.:90; in eie Afrikaanse vertaling). 
Ook die voorbidding van Abraham vir Sodom (Gen. 18) toon tipiese trekke van die gebed in hierdie tyd. Abraham is al te bewus van sy nederigheid voor God, en tog bid hy die Here om die stad te spaar ter wille van die regverdiges daarin, van vyftig tot uiteindelik net tien, en elke keer gee die Here toe aan sy versoek. Dit is 'n ongelooflik vrymoedige versoek aan die Here, terwyl Abraham erken dat hy net stof en as is (Gen. 18:27); tog waag hy dit!

\section{Gebede van die uittog tot met die ballingskap}

In die tyd van die uittog uit Egipte tot met die ballingskap kry die ordening van volk en staat al duideliker en vaster kontoere, en blyk dit ook uit die gebede wat opgeteken is dat daar persone in amptelike posisies is wat die gebede bedien: profeet, priester en koning. Moses, Aäron, Samuel, Salomo en Hiskia is van die groot leiers wie se gebede vir ons opgeteken is. God verhoor soms die spesifieke gebede (Hiskia, 2 Kon. 19:14-19), maar Hy is vry om 'n gebed ook nie te verhoor nie (Amos 7), en Jeremia word selfs verbied om vir die volk te bid (Amos 7:16; $11: 14 ; 14: 11)$.

Van die bekendste gebede uit hierdie tyd is, behalwe in die Psalms, juis die gebede van profete soos Jesaja en Jeremia, Habakuk en Daniël. Uiteraard het hierdie profete in 'n baie innige verhouding met God gestaan as ontvangers van die geopenbaarde Woord, en dit is te begryp dat hierdie verhouding hulle ook meer dikwels tot gebedsworsteling met God gelei het.

\subsection{Moses se gebed vir die volk (Eks. 32:11-33:16)}

Wanneer Moses hier vir die volk intree by die Here, staan die laer nog by die Sinaiberg. Na die verbondsluiting (Eks. 24:1-8) het Moses vir Josua saamgeneem en hoër teen die berg opgeklim totdat Moses uiteindelik alleen in die wolk op die berg ingegaan het (Eks. 24:18), waar hy vir veertig dae gebly het. Intussen het die volk die sonde met die aanbidding van die goue kalf begaan (Eks. 32). Die Here het in sy toom besluit om die volk uit te wis en om uit Moses vir Hom 'n volk tot stand te bring (Eks. 32:10).

Moses tree dan vir die eerste keer vir die volk in. Met 'n beroep op die verbond en op die beskimping van die Egiptenare smeek hy dat die Here nie hierdie ramp oor sy volk moet bring nie (32:11-13).

Die Here verhoor Moses se gebed en bring sy besluit nie tot uitvoering nie. Moses en Josua kom van die berg af na die kamp toe, Moses gooi die kliptafels stukkend, vernietig die goue kalf, en laat die Leviete drie duisend man onder die volk om die lewe bring. Moses belowe dan dat hy by die Here om vergifnis vir die volk sal pleit $(32: 30)$. 
Dan volg Moses se tweede pleitrede vir die volk. Nou is dit nie meer die afweer van die ramp waarom dit gaan nie, maar om sondevergifnis. So ernstig is Moses se pleitrede dat hy sy lewe daarmee op die spel wil plaas. As die Here die volk nie wil vergeef nie, moet die Here sy naam uitvee uit die boek wat die Here skryf (32:32).

Die antwoord wat die Here hierop aan Moses gee, is dat dié wat gesondig het, uitgedelg moet word. Hy wil Moses se lewe nie in die plek van die sondige volk aanvaar nie, maar Hy gee aan Moses opdrag om die reis voort te sit en Hy beloof dat sy engel sal meetrek om hulle die land in besit te laat neem. Die volk gaan in rou wanneer hulle hierdie uitspraak hoor. Intussen rig Moses die tent van ontmoeting op buite die laer, waar God met Moses praat soos 'n man met sy vriend praat.

Later ("op 'n keer", 33:12) pleit Moses weer tot die Here. Die engel wat die Here beloof het, kom nie in Moses se pleitrede voor nie, maar dit is duidelik dat dit vir Moses nie aanvaarbaar is nie. Hy vra, asof die Here niks gesê het nie, dat die Here hom nie bekend gemaak het wie met hulle sal saamtrek nie. Maar as die Here hom dan "goedgesind" is, vra hy dat die Here sy wil aan hom bekend sal maak. Die Here antwoord só op Moses se vraag dat dit duidelik is dat Hy begryp dat dit eintlik beteken dat Moses wil hê dịe Here self moet meetrek. Die Here stem ook hiertoe in (33:17). Daarna versoek Moses dat hy die magtige verskyning (OAV: heerlikheid) van die Here mag sien (Eks. 33:18).

Dit is duidelik dat die kere waartydens Moses vir die volk ingetree het, as een geheel gesien moet word. Dit is een gebed van Moses vir die volk. Ook die versoek van Moses om die heerlikheid van die Here te mag sien, hang hiermee saam.

In die lyn van hierdie dialooggebed (kyk Velema, 1978:10 e.v.) van die middelaar Moses word dit waaroor dit gaan al hoe duideliker. In die gloed van God se toom oor die sonde van die volk is die eerste gevaar dat die sonde sal lei tot die uitwissing van die volk. Deur Moses se pleit word dít afgewend. Dit is egter nie die einde nie. Die vraag is of die verhouding van God met die volk herstel sal word. Juis hierin kom die krag van Moses as middelaarsfiguur na vore: sy onophoudelike worsteling lei dieper en dieper tot die kern van die verhouding met God. Dit gaan nie net om fisiese beskerming nie. Eindelik gaan dit ook nie net om sondevergifnis nie, maar dit gaan om 'n lewe mét God. In die beskrywing van Moses se worsteling met God word die volk nooit geregverdig nie. Hulle bly sondig, en die erkenning is daar dat hulle voortdurend weer sal oortree. Tog is die Here bereid om die middelaar, Moses, se pleitrede te aanvaar en om in Moses weer met die volk op weg te gaan. 
Hierin lê juis ook die betekenisvolheid van Moses se versoek om die heerlikheid van die Here te sien. Dit is die bevestiging dat Moses se pleit verhoor word, want die heerlikheid van die Here is die manifestasie van sy teenwoordigheid Moses kon die openbaring van die heerlikheid van die Here beleef soveel as wat vir die gelowige mens in die Ou-Testamentiese bedeling beskore was. En dit het vir hierdie middelaarfiguur die gerustheid van gebedsverhoring gebring. Hy kon die teenwoordigheid van die Here ervaar - nie net as belofte nie, maar as oorweldigende werklikheid.

Vir ons eie gebedslewe lê hierin geweldige ryk aanduidings. Die omgang met God as dialoog met die Woord, en as dialoog met die werke van God in ons lewe moet 'n seker grondslag van ons gebed wees. Dit kan nie net 'n blote intellektuele of 'n blote emosionele oefening wees nie. Dit moet uiting wees van 'n oorgegewe lewe vóór God en mét God.

Sondevergifnis, wat meestal prominent, maar dikwels meganies in ons eie gebede funksioneer, moet ook nie bloot 'n meganisme word waardeur ons veg om die behoud en redding van ons eie lewe nie. Wanneer dit ten diepste daarom gaan dat ons pleit om sondevergifnis omdat ons God nie as gevolg van ons sonde wil verloor nie, en omdat ons met Hom op ons lewenspad verder wil gaan, dan het die bede om sondevergifnis ' $n$ dimensie bygekry. Hierdie dimensie laat juis die werk van Jesus Christus in sy volheid as Middelaar tussen God en mens tot sy reg kom. Waar die Ou-Testamentiese bedeling moes volstaan met 'n aanskoue van die heerlikheid van die Here agter sy hand en met 'n uitroep van die "Naam van die Here", het die Nuwe-Testamentiese bedeling die openbaring van God se teenwoordigheid in die Seun (Kol. 2:9: "in Hom is die volle wese van God beliggaam"), en het die gebede in die naam van ons Here Jesus Christus alreeds die versekering van gebedsverhoring.

\subsection{Salomo se gebed by die inwyding van die tempel (1 Kon. 8:22-61; 2 Kron. 6)}

Hierdie is 'n baie plegtige gebed tydens 'n baie plegtige, openbare geleentheid. Die gebedshouding van Salomo is vir die volk 'n aanskoulike voorbeeld van ware verootmoediging voor die Here. Hy staan voor die altaar, die gereelde versoeningsplek van die volk, teenoor die volk, met sy hande na die hemel toe opgehef, terwyl 2 Kronieke meld dat hy dan teenoor die volk op die koperverhoog neerkniel.

In die aanhef van die gebed word God op oorwoë, lofprysende manier in sy absolute enigheid gehandhaaf, terwyl die volk dan juis aan hierdie enige God gebind word deur 'n beroep op die verbond, eers as algemene uitdrukking om die verhouding van God tot die volk uit te druk, maar dan spesifiek die verbond wat 
die Here met Dawid aangegaan het. Salomo is onder die indruk daarvan dat hy die direkte vervulling van die verbondsbelofte aan Dawid is, en as sodanig ook die verteenwoordiger en middelaar in Dawid se plek.

Salomo se pleit om gebedsverhoring word in sy gebed gegrond op die feit dat die Here sy Naam in die tempel wil laat woon. Salomo is wel bewus van die grootheid van die Here, sodanig dat Hy nie in ' $n$ aardse gebou vasgevang kan word nie, en dat selfs die hemel Hom nie kan bevat nie. Waar dit hier gaan om die inwyding van die tempel as woonplek van die "Naam van die Here", is die inwoning van die Here in die tempel die grondslag vir die verhoring van die gebede van die volk by hierdie plek, of selfs in die rigting van hierdie plek. Ten diepste gaan dit hier dus weer, net soos in die geval Moses, om God en sy teenwoordigheid in die lewe en by die gebede van die bidder. Salomo bid dat die volk se gebede verhoor mag word wanneer hulle onder verskillende omstandighede gesondig het en dan tot inkeer gekom het "sodat hulle U kan vrees al die dae wat hulle leef in die land wat $U$ aan ons vaders gegee het" (1 Kon. 8:40, OAV). Dit is belangrik dat Salomo nie oppervlakkig vra om blote vergifnis van hulle oortreding nie, maar in diepergaande bewoording impliseer hy dat vergifnis die betekenis het dat die volk in gehoorsaamheid sal leef, dat hulle noukeurig volgens die uitdruklike en bekende wil van die Here sal optree. So sal hulle nie die toom van die Here opwek en hulleself van Hom af verdryf nie. Alleen dan kan die Here by hulle teenwoordig bly, en kan hulle sy volk wees.

In tipiese Ou-Testamentiese perspektief vra Salomo ook dat die uitlander wat in opregtheid hier kom bid, eweneens verhoor sal word, "sodat al die volke van die aarde u Naam kan ken en ook aan U gehoorsaam kan wees net soos u volk Israel, en dat hulle kan weet $\mathrm{u}$ Naam is uitgeroep oor hierdie tempel wat ek gebou het" (1 Kon. 8:43, NAV). Die grondslag van hierdie bede is veel minder 'n bekommernis om die redding van die nasies, as dat die eer van die Here tot sy reg moet kom. Anders geformuleer kan ons sê dat die ernstige begeerte dat die eer van die Here tot sy reg moet kom, insluit dat alle mense as skepsele van God in gehoorsaamheid aan Hom hulle volle menswees moet uitleef.

Belangrik vir ons eie gebede is die feit dat albei weergawes van hierdie gebed, naamlik 1 Konings 8 en 2 Kronieke 6, eindig met 'n lofverheffing, hoewel dit in die twee weergawes nie dieselfde is nie. Die enigheid van God, sy mag en sy verhewenheid kan in albei egter sterk aangevoel word.

Terwyl die sonde wat die volk begaan het die aanleiding van Moses se gebed was, is die gebed van Salomo 'n profetiese blik op die toekomstige geskiedenis van die volk. By albei gaan dit egter om die volk aan God te bind. Die tempel staan by die gebed van Salomo in die sentrum, maar Salomo is ook daarvan bewus dat die tempel God nie beperk nie, nie geografies nie, maar ook nie in die tyd nie. Dit gaan om waar die Naam van die Here woon. Vir ons in die Nuwe- 
Testamentiese bedeling is die Here steeds daar waar "die ware aanbidders die Vader deur die Gees en in waarheid sal aanbid" (Joh. 4:23, NAV).

\subsection{Hiskia se gebed by die Assiriese dreiging (2 Kon. 19:15-19)}

Heelwat later in die geskiedenis volg die gebed van Hiskia wanneer die Assiriese magte Jerusalem bedreig. Die Assiriese koning stuur 'n brief aan Hiskia waarin hy spog dat die gode van die Aramese state die ander volke nie kon help nie, en daarom waarsku hy Hiskia om nie op die Here te vertrou nie. Dit is 'n soort van bedreiging en heidense optrede wat die volk van die Here tot nog toe nie veel teëgekom het nie. Die mag van die groot ryk, die eerste waarvan die volk nou die geweld gevoel het, het Hiskia verslae gemaak. In kinderlike geloof gaan hy alleen na die tempel toe, lê die brief daar voor die Here en bid daar tot die Here.

In die aanroeping van sy gebed benadruk Hiskia God se groot mag as Skepper en sy heerskappy oor al die koninkryke van die aarde. Die ontsteltenis in sy gemoed ontstaan op grond van die feit dat die Here toelaat dat die Assiriese koning, Sanherib, die Here smaad, of beledig, terwyl die heidense koning spog dat hy die oorwinning behaal het oor ander volke se gode, terwyl hulle in werklikheid geen gode is nie. Al die koninkryke moet tog weet dat die Here alleen God is. Die redding uit die mag van die heidense Sanherib, waarvoor Hiskia bid, gaan dus ten diepste weer nie om die volk se behoud as sodanig nie, maar om die eer van die Here. In sy verbondenheid aan die Here bring die redding van die volk die eer van die Here in hierdie situasie tot sy reg, en daarom is dit korrek om te bid vir die redding van die volk, die Here se volk. Die doel van die verlossing word egter duidelik gestel: al die koninkryke van die aarde moet besef dat daar net hierdie een God is.

Daar is baie maniere waarop God in die gebed aangeroep is en aangeroep kan word, maar dit is gepas om by bepaalde geleenthede die aanroeping te formuleer op 'n wyse wat by die aard van daardie geleentheid pas. God is immers ook in hierdie wêreld besig met sy kinders, en daar is geen rede om in elke situasie nie ook God aan te roep op 'n wyse waarop sy teenwoordigheid en mag vir daardie situasie van toepassing is nie. Daarom is Hy vir Hiskia hier "God van Israel", die Een wat "oor die gerubs troon", "God oor al die koninkryke van die aarde", meer nog, die Een wat "die hemel en die aarde gemaak het".

Die gebed om selfbehoud, die gebed uit benoudheid en vrees, kan in ons eie gebede maklik oorspan word. By Hiskia het 'n mens nie die indruk dat hy uit angs en vertwyfeling bloot pleit om gespaar te mag bly nie. Hy bid wel met groot erns en dringendheid, maar daar is 'n rustigheid en verhewenheid in sy gebed wat spruit uit die sekerheid van die geloof dat Jahwe alleen God is en dat alle volke voor Hom moet buig. Die behoud van koning en volk onder hierdie bedreiging uit moet daarom ook daartoe lei dat die Here deur al die volke erken en geëer 
word. Hierdie "missionêre spits" van Hiskia se gebed (Velema, 1978:56) moet in ons eie gebede ook steeds 'n rol speel.

\subsection{Jeremia se gebed vir die volk (Jer. 14)}

Jeremia tree op in die krisistyd van Israel se bestaan. Die geskiedenis van die volk is besig om met spoed op 'n geweldige ramp af te stuur. Naas die geestelike verval van die volk kom nou ook nog twee rampe oor die volk: die natuurramp van 'n groot droogte, wat in die land van Israel meermale voorgekom het en die ramp van oorlogsgeweld. Die erns van die rampe verbeeld die diepte van die geestelike agteruitgang van die volk. Jeremia is in ' $n$ totaal verslae toestand.

Die twee gebede in hoofstuk 14, wat in poetiese vorm voorkom, vertoon groot ooreenkoms met mekaar, en het 'n komplekse struktuur (kyk Nicholson, 1970: 100-102) wat soos volg voorgestel kan word:

$\begin{array}{lll}\text { Bede } 1 & \text { Bede } 2 & \text { Beskrywing } \\ \text { vs. } 1-6 & \text { vs. } 17-18 & \text { Toestand van die volk } \\ & \text { vs. } 19 & \text { Waarom het God dit gebring? } \\ \text { vs. } 7 & \text { vs. } 20 & \text { Skuldbelydenis } \\ \text { vs. } 8-9 \mathrm{a} & \text { vs. } 21 & \text { Smeekbede } \\ \text { vs. } 10 & & \text { Wee-uitspraak }\end{array}$

vs. 22 Uitspraak van vertroue

Die vorm van die gebede kom baie ooreen met die tipiese vorm van die klaagliedere van die enkeling. Gewoonlik eindig die klaaglied in 'n uitspraak van vertroue, wat hier net in Bede 2 voorkom.

Belydenis van die volk se skuld kom in albei gebede sterk op die voorgrond. Die oortredinge van die volk is die rede vir Jahwe se straf. In Bede 1 word genoem: ongeregtigheid, afkerigheid. Bede 2 bring die onvermoë van profeet en priester om die volk reg te leer ook in die visier, nadat Jahwe self hulle as valse profete uitgewys het (vs. 13-16). Dit is 'n volk wat in sy totaliteit niks anders as die straf van Jahwe verdien nie.

Jeremia toon 'n uiterste bewoënheid oor die lot van die volk, maar tog alleen omdat hulle God se volk is, wat deur die verbond aan Hom verbind is. Dit lê ook in sy aanspreekvorm van God as "Verwagting van Israel, sy Verlosser in tyd van benoudheid (vs. 8, OAV; NAV vertaal: "Hoop van Israel, Redder in tyd van nood"). Op hierdie verbondenheid van die volk aan God berus ook die 
versugting van Jeremia dat God permanent by sy volk moet woon: God moet nie soos ' $\mathrm{n}$ reisiger net in die verbygaan uitdraai om by hulle te oomag nie (vs. 8). God moet dus nie net af en toe iets van sy teenwoordigheid in die geskiedenis en die lot van sy volk laat sien nie!

Nadat Jeremia ernstig gesmeek het dat die Here hulle tog nie moet verlaat nie, verbied die Here hom om vir die volk voorspraak te doen; Hy gaan hulle nie meer verskoon nie (vs. 10). Tog gaan Jeremia voort om vir hulle te pleit. Wanneer hy in die tweede bede kla oor die smartlike lot van die volk as gevolg van die oorlogsgeweld, en hy namens die volk belydenis doen van sonde en opstandigheid (vs. 20), dan is twee dinge baie opmerklik in sy gebed.

- Eerstens is dit vir Jeremia duidelik dat die oorlogsgeweld, wat deur ' $\mathrm{n}$ vyand oor hulle gebring word, eintlik van die Here self afkomstig is. Hy weet dit helder en duidelik. Geen vyand word by name genoem nie. Dit is die Here wat dit alles bewerk. Het die Here hulle dan verwerp? Nee, dit kan nie. Die volk is God se volk op grond van die verbond wat die Here self met hulle gesluit het. Daarom is Jeremia se pleit op grond van hierdie verbond nie in die laaste instansie om die volk se onthalwe nie, maar "ter wille van U Naam" (vs. 21).

- Tweedens is daar vir Jeremia geen ander heenkome nie, en werp hy hom geheel en al op die Here. 'n Baie sterk uitdrukking van die pleit-karakter van Jeremia se gebed is hierdie laaste woord: "Ons wag op U" (OAV), of: "Ons vertrou op U" (NAV). Die Hebreeuse woord (Pi'el van qwh) het iets van die betekenis van "met spanningsvolle afwagting en vol vertroue uitsien na die optrede van die Here". In die situasie waarin die volk verkeer, wat 'n hopelose situasie is onder die smarte van ' $n$ uitmergelende droogte, en onder die teistering van 'n oorlog waar dood en verwoesting gesaai word, erken Jeremia dat die volk uit eie krag niks kan vermag nie. By die Here is daar egter hoop, want Hy doen al hierdie dinge!

Die vraag ontstaan nou of die Here hierdie gebed van Jeremia verhoor het. God het dan self vir Jeremia gesê om nie meer vir die volk voorspraak te doen nie, nie meer vir die volk te bid nie. Hy het vas besluit om met hulle te handel volgens hulle oortredings. Die geskiedenis nog tydens die lewe van Jeremia vertel duidelik hoe die volk hulle eie ondergang en die verwoesting van die stad en die tempel beleef het. Met die wegvoering in ballingskap het hulle alle vastigheid ook in hulle eie godsdienstige uitkyk - verloor, en moes hulle in Babel sit en treur oor die verwoesting van Jerusalem.

Tog het die Here hierdie gebed wel verhoor. Hy het sy volk nié verwerp nie. Hy het wel genesing gebring. Hy hét sy volk verlos, maar op 'n ander wyse, op 'n ander tyd, en op 'n ander vlak as waarvoor Jeremia ter wille van die volk gebid 
het, en as waarop die volk gehoop het. In die volheid van die tyd hét Hy die eer van sy Naam gehandhaaf en sy verbond gehou.

Dit is belangrik om dit steeds in gedagte te hou - ook in ons eie gebede. Die Here bly getrou. Die uitkoms wat Hy bring op situasies wat vir ons ondraaglik en hopeloos lyk, is dikwels, miskien meestal, anders as wat ons dink of waarop ons hoop. Tog gaan dit, en moet dit in ons gebede gaan om die eer van sy Naam terwyl ons steeds daaraan kan vashou dat Hy getrou is - getrou aan sy geregtigheid, sy liefde, sy heiligheid en sy ontferming. As ons gebede nie daarop ingestel is nie, maar eerder op ons eie persoonlike ervaring, kan wat Hy doen vir ons na onverhoorde gebede lyk. Sy trou is egter die waarborg dat Hy wat alles gedoen het en nou nog alles doen, ook in sy wysheid as antwoord op ons gebede doen wat tot die voleinding van sy verheerliking dien. Daarom kan ons ook, soos Jeremia, met groot gerustheid en vaste veitroue op Hom bly wag.

\section{Gebede in die tyd na die ballingskap}

Die tyd van die ballingskap het ' $n$ taamlike verandering in die gestalte van die godsdienstige lewe van die volk tot gevolg gehad. Met die verwoesting van die tempel het die tempel self as sentrale punt van die gebede van die volk (vgl. die gebed van Salomo) verval, en is die offerdiens saam met die ander kultiese handelinge tot stilstand gebring. Dit kon nie in die vreemde land van ballingskap voortgesit word nie. Die bewustheid onder die volk dat hulle nogtans die volk van die Here, volk van die verbond is, het egter bly voortbestaan, veral deur die werksaamheid van profete soos Jeremia en Esegiël. Daar het 'n nuwe belewing van die godsdiens van die volk en van hulle verbondenheid aan die Here ontstaan, soos uitgedruk in die boek Klaagliedere. Dit het in die praktiese uitlewing van hulle godsdiens in die ballingskap daartoe gelei dat naas godsdienstige verpligtinge soos besnydenis, vas en onderhouding van die Sabbat, veral die gebed ook ' $n$ belangrike plek ingeneem het (Herrmann, 1935:785). Na die terugkeer uit die ballingskap het die herbou van die tempel en die herstel van die offerdiens nie die verworwe plek van die gebed verdring nie. Die gebed neem dan ' $n$ meer spontane karakter van eenvoud aan, sonder vaste orde en reëls, en in 'n soveel sterker bewustheid van die alomteenwoordigheid van God Wie se aangesig in die gebed gesoek word.

\subsection{Daniël se gebed om die toekoms (Dan. 9:2-19)}

Eintlik het enige gebed iets met die toekoms te make. Sommige gebede, soos hierdie een van Daniël, is egter meer spesifiek op die toekoms gerig. Dit volg uit die feit dat Daniël in gebed oorgaan nadat hy die profesie van Jeremia oor die sewentig jaar ballingskap bestudeer het (Jer. 25:12; 29:10). Die gebed van Daniël moet daarom gedateer word waarskynlik in die eerste jaar van die Persiese oorheersing na die inname van Babel en nog voor die terugkeer uit die 
ballingskap en die herstel van die tempel en die stad (kyk Baldwin, 1978:163164).

Die gebed van Daniël dra duidelik die kenmerke van die na-ballingskapse tyd, en met name is daar duidelike ooreenstemming met die gebede van Nehemia, byvoorbeeld die vas voor die gebed (vgl. Neh. 1:4); die uitdrukking "my God", wat baie skaars is in vroeerre gebede, maar wat verskillende kere by Nehemia voorkom (bv. Neh. 5:19; 6:14; 13:29, 31). Ook die doksologie in die aanroeping van God kom ooreen met die doksologie in die gebed van Nehemia.

Die inleiding van Daniël se gebed bestaan uit ' $n$ uitgebreide skuldbelydenis, wat ná die doksologie wys op Daniël se selfvernedering voor God (vgl. dieselfde by Nehemia in 1:5-7). Juis hierdie selfvernedering word trouens 'n kenmerk van die apokaliptiek van Daniël genoem (Lebram, 1989:187).

In sy hartroerende gebed bid Daniël ter wille van die verwoeste heiligdom (vs. 17), en doen hy 'n beroep op die barmhartigheid van die Here (vs. 18), want die Naam van die Here is oor sy stad en sy volk uitgeroep (vs. 19). Hoewel Daniël dit nie uitdruklik sê nie, is sy bede dat die stad herstel word, en dat die volk nie ten gronde gaan nie, maar as volk van die Here mag bly voortbestaan. Die ooreenstemming met die bewoording van Jeremia se gebed is opvallend, maar juis verstaanbaar, aangesien Jeremia se woorde die aanleiding tot sy gebed is.

Daniël verkry 'n antwoord op sy gebed, iets wat nie altyd so duidelik by die ander gebede voorkom nie, en die antwoord omvat veel meer as net die weeroprigting van die puinhope van Jerusalem. Dit dui daarop dat die periode van sewentig jaar in die profesie van Jeremia nie bloot gesien moet word as 'n numeriese aanduiding nie, maar dat dit veel eerder teologiese inhoud het (Baldwin, 1978:164). Daarom open Daniël se gebed nie net 'n blik op die letterlike vervulling van Jeremia se profesie met betrekking tot die herstel van Jenusalem nie, maar dit bied inderdaad die wyer blik van die profetiese perspektief. Hierdie perspektief sluit ook die herstel van Jerusalem in, maar dui verder profeties-apokalipties die heilsplan van God tot die einde toe aan.

Hierdie gebed van Daniël dra besondere betekenis vir ons eie tyd. Juis vandag kan die hopeloosheid van verskillende situasies nie losgemaak word van die sonde van die volk nie - die gedane sonde en die voortgaande ongehoorsaamheid en afwyking van die geopenbaarde wil van die Here. Enige gebed vir die land moet dus gedra word deur ' $n$ hartgrondige skuldbelydenis.

Aan die ander kant leer ons juis uit die antwoord op Daniel se gebed, soos trouens ook elders in Daniël, dat daar steeds tot die einde toe rampe en oorlog en hopelose situasies sal wees. Die lewe sal nie makliker word nie. Volharding in die geloof kan om hierdie rede nie gedra word deur 'n blote versugting dat die 
ellende van ons afgeweer moet word nie. As daar nie, soos by Daniël, ook 'n perspektief is op die herstel van die eer van God, en 'n vaste geloof dat die aanbreek van die koninkryk van die hemele volle vrede en geregtigheid en heerlikheid in eskatologiese sin sal bring nie, sal ons gebede hol en leeg bly. Die toekoms is nie bloot tye wat nog kom nie, maar impliseer die koms van God in die volheid van sy verlossing en heil, sy mag en sy heerlikheid.

\section{Samevatting}

Samevattend kan ons die volgende sê oor die gebed soos dit uit die Ou Testament geken word:

- Die gebed kom voort uit 'n baie innige geloofslewe in voortdurende gemeenskap met God. Waar die geloofslewe met God verwaarloos of moedswillig verbreek word, verloor die gebed nie net sy krag nie, maar vind dit, net soos by rituele gebruike, geen guns by God nie. Daarom moet die gebed ook nooit verval in meganiese handelinge of 'n dodelike sleurgang sonder betekenisvolle inhoud nie. Dan sou ons gebede beantwoord aan die beskrywing van Van Niftrik wat, vry vertaal, soos volg lui:

Ons gebedslewe is dikwels nie meer as sleur nie. Ons open ons vergaderings 'op die gebruiklike wyse', ons bid voor en na ete, ons bid as ons gaan slaap en as ons opstaan. Vir sover ons gebede iets meer is as 'n Christelike stempel, lyk dit na 'n treintjie uit die Achterhoek, wat elke dag [by] dieselfde stasietjie aandoen, en dan verder puf totdat die eindstasie bereik is (Van Niftrik, 1953:352).

- Die gebed is nie gebonde aan tyd of plek of status van die persoon of die geleentheid nie. God kan te eniger tyd genader word, en daar is selfs plek vir die "skietgebed" (NAV) soos ons dit by Nehemia vind (Neh. 2:4).

- 'n Plegtige geleentheid vereis wel 'n plegtige gebed wat vir die geleentheid goed gekonstrueer is en wat voldoende aandag gee aan die gebedseise ten aansien van die aanroep van God en die behoeftes van die byeenkoms wat by die geleentheid moet kan saambid. Taal en styl, die voorkoms van die voorganger en stylvolle optrede moet hiermee saam in berekening gebring word. Dit hou ook in dat daar steeds deeglike voorbereiding van die gebed en vir die gebed moet wees. Du Toit (1961:90) het al gesê: "Terselfdertyd wil ek ook erken dat ons, predikante, ons nie altyd met genoegsame erns vir die gebed voorberei nie".

- 'n Balans moet in die gebed gevind word tussen breedsprakigheid, 'n waardige aanroep van God, kinderlike vertroue en 'n gepaste onder woorde bring van die wesenlike behoeftes. 
- Die bepaling van wesenlike behoeftes moet nie op emosionele gronde berus en nie bloot die oppervlakkige behoeftes van die betrokke gemeenskap, of hulle eie, persoonlike aspirasies omvat nie. Van Niftrik sê ook dat ons gebed dikwels lyk soos die indien van 'n wenslysie by die Here God, soos kinders by hulle verjaardag 'n wenslysie opstel. As ons dan nie kry wat ons graag wil hê nie, sê ons dat God nie ons gebed verhoor nie. Dan begin ons swaarwigtig diskusseer oor die probleem van gebedsverhoring (kyk Van Niftrik, 1953: 352). Ons gebed moet inteendeel die weerspieëling wees van 'n goed deurleefde verstaan van die godsdienstige behoeftes van onsself of van die gemeenskap, wat na vore kom uit 'n ernstige studie van die Woord van God.

- Gebed wys altyd heen na die toekoms, maar die blik op die toekoms moet nie net 'n poging wees om mense in hulle situasie van ongemak te sus nie; dit moet veral God se toekoms op die oog hê.

- So moet die bidder veral weet dat die gebedsbediening beteken dat hy as voorbidder optree vir ander. Tog bly daar 'n plek vir die persoonlike behoeftes, ook in die gebedsbediening, veral waar sowel die predikant as bidder én die gemeente weet dat hy as geroepene in 'n ampshoedanigheid optree.

- Uiteraard sal ons gebede gedra word deur die wete dat Christus die vervulling van ons gebede is, en dat ons daarom saam met en deur die Heilige Gees bid. Juis hierdie wete versterk egter die gebedshandeling as 'n verskyn voor die hoè God van hemel en aarde. Terwyl ons daarom steeds bewus sal bly van ons eie tekortkominge en swakhede, kan ons met soveel meer vrymoedigheid bid.

\section{Bibliografie}

ALBERTZ, R. 1976. 'ir beten. (In Jenni, E. \& Westermann, C., Theologisches Handworterbuch zum Alten Testament. München : Kaiser Verlag. p. 386.)

ALLEN, R.B. 1981. ir. (In Harris R.L., Archer, G.L. (jr.), Waldtke, B.K. Theological wordbook of the Old Testament. Chicago : Moody Press. p. 709.)

BALDWIN, J.C. 1978. Daniel. An introduction and commentary. (Tyndale Old Testament commentaries). Leicester : Inter-Varsity Press.

DE VAUX, R. 1973. Hoe het oude Israel leefde. 2 vols. Roermond : Romen.

DU TOIT, J.D. 1961. Versamelde werke. Johannesburg : Dagbreek Boekhandel. DI. VII.

HAMILTON, V.P. 1981. pll. (In Harris, R.L., Archer, G.L. (jr.), Waldtke, B.K. Theological wordbook of the Old Testament. Chicago : Moody Press. p. 726.)

HERRMANN, J. 1935. s.v. euxomai. (In Kittel, G. ed. Theologisches Worterbuch zum Neuen Testament. Stuttgart : Kohlhammer. p. 782-799.) 
KRAUS, H.-J. 1988. Psalms 1-59. A commentary (transl.). Minneapolis : Augsburg Publ. House.

LEBRAM, J.C.H. 1989. The piety of the Jewish apocalyptists (In Hellholm D. ed. Apocalypticism in the Mediterranean world and the Near East. Tubingen : Mohr. p. 183-195.)

NICHOLSON, E.W. 1970. Preaching to the exiles. A study of the prose tradition in the book of Jeremiah. Oxford : Blackwell.

NOREL, O. s.j. Het gebed in den Bijbel. Baarn : Bosch \& Keuning.

STÄHLI, H.-P. 1976. pll hitp: beten. (In Jenni, E. \& Westermann, C., Theologisches Handwörterbuch zum Alten Testament. München : Kaiser Verlag. p. 427-432.)

VAN NIFTRIK, G.C. 1953. Kleine Dogmatiek. Nijkerk : Callenbach.

VELEMA, W.H. 1978. Gebeden in de Bijbel. Kampen : Kok. 
